\title{
Rıza Tevfik'in Güzel Sanat Hakkında Manzum Bir Musahabe Şiirine Yansıyan Romantik Sanat Algisı
}

\section{Dr. Öğretim Üyesi Ulaş Bingöl ${ }^{1 *}$}

Geliş tarihi: 09.11.2019

Kabul tarihi: 31.12 .2019

\section{Atıf bilgisi:}

IBAD Sosyal Bilimler Dergisi

Sayı: $6 \quad$ Sayfa: $102-116$

Yll: 2020 Dönem: Kış

This article was checked by iThenticate. Similarity Index 7\%

Bu makalede araştırma ve yayın etiğine uyulmuştur.

* Siirt Üniversitesi, Türkiye, ulasedebivat@gmail.com

ORCID ID 0000-0003-3093-1036

*Sorumlu yazar öz

Sanatsal yaratım, sanatçının kişiliği, estetik değer ve yargılar, kadim estetikten bugüne kadar sanat felsefesinin üzerinde durduğu belli başlı konulardandır. Sanatçının eserini ortaya koyarken içinde bulunduğu ruhsal vaziyeti ve bu ruhsal vaziyetin özgünlüğünü ele alan düşünürler, insanlığın ayırt edici faaliyetlerinden birinin sanat olduğunu vurgularlar. Kimi şairler de sanat üzerine fikirlerini dile getirerek estetik disiplininin ve sanat felsefesinin gelişimine katkı sağlar. Alman şair ve filozof Schiller, Servet-i Fünûn edebiyatının önemli isimlerinde Tevfik Fikret, şiir yoluyla sanat hakkındaki görüşlerini dile getiren bazı kişilerdir. Şiir yoluyla sanat felsefesi ve estetik hakkında düşüncelerini ifade eden șairlerden biri aynı zamanda felsefeyle ilgilenen Riza Tevfik'tir. Onun Serab-ı Ömrüm kitabında yer alan Güzel Sanat Hakkında Manzum Bir Musahabe șiiri sanat felsefesi metni görünümündedir. Sanatçı, sanat, estetik değer ve estetik yargı konularına değinen şair, adeta bir filozof gibi sanatın felsefî çözümlemesini yapar. Rıza Tevfik, sanatçının diğer insanlardan farkı; insanın sanat eserini ortaya koyarken içinde bulunduğu ruh hali ve bu ruh halinin niteliği üzerinde durarak hayvan ile insan arasındaki temel ayırımlardan birinin estetik duygu olduğunu belirtir. Beș bölümden oluşan şiirin her bir bölümünde sanatın farklı bir özelliğine dikkat çeker. Birinci bölümde sanat eserini ortaya koyan sanatçıyı; ikinci bölümde sanatçılar arasında şairin yeri ve özgünlüğünü; üçüncü bölümde sanat ile ilim arasındaki fark1; dördüncü bölümde âlim ile sanatçı arasındaki telakki farkını; beşinci bölümde sanatçının insanları nasıl etkilediğini işler. Rıza Tevfik'in şiirinde ortaya konulan görüşlerin romantik sanat anlayışı ile paralellik gösterdiği gözlemlenir. $\mathrm{Bu}$ çalıșmanın amacı, Rıza Tevfik'in Güzel Sanat Hakkında Manzum Bir Musahabe şiirinde ileri sürdüğü fikirler ile romantik sanat anlayışı arasındaki paralellikleri ortaya koyup incelemektir.

Anahtar Kelimeler: Rıza Tevfik, Şiir, Estetik, Romantizm. 


\title{
The Perception of Romantic Art Reflected in Güzel Sanat Hakkında Manzum Bir Muhasebe Written by Riza Tevfik
}

\author{
Assist. Prof. Dr. Ulaş Bingöl ${ }^{*}$
}

First received: 09.11.2019

Accepted: 31.12 .2019

\section{Citation:}

IBAD Journal of Social Sciences

Issue: 6

Pages: $102-116$

Year: 2020

This article was checked by iThenticate. Similarity Index 7\%

${ }^{1}$ Siirt Üniversity, Turkey, ulasedebiyat@gmail.com

ORCID ID 0000-0003-3093-1036

\section{* Corresponding Author}

\begin{abstract}
Artistic creation, aesthetic values and judgments, artistic personality are the main issues which art philosophy deliberates on them from ancient aesthetics up to now. Philosophers who handle artist's spiritual and its state when he or she exhibits his work emphasize that art is one of the distinctive activities of humanity. Also, some poets contribute to progress of aesthetics and art philosophy by mentioning his thought about art. German poet and philosopher Schiller, Tevfik Fikret, who is one of the leading poets in Servet-i Fünûn period, are among poets who express his thought about art by poetry. Also, Riza Tevfik, who is interested in philosophy, states his thought about art by poetry. His poetry named Güzel Sanat Hakkinda Manzum Bir Musahabe, which it is situated in Serab-l Ömrüm, purports a philosophical text. Riza Tevfik, who states his opinion about artist, art, aesthetic value and aesthetic judgment, analyzes to art as a philosopher. He indicates that basic distinction between man and animal is aesthetic pleasure by emphasizing on the difference of the artist from other people, human mood when he reveal an artwork. He points to a different characteristic of art in the poem, which it comprise of five chapters. He handles artist in first chapter, a poet among artists and originality in the second chapter, the difference between art and science in the third chapter, the difference of understanding between scholar and artist in the fourth chapters, how the artist affects people in the fifth chapter. It is observed that ideas in Riza Tevfik's poem resemble romantic art perception from many perspective. The aim of this paper is to investigate to resemblance between Riza Tevfik poetry named Güzel Sanat Hakkında Manzum Bir Musahabe and romanticism.
\end{abstract}

Anahtar Kelimeler: Riza Tevfik, Poetry, Aesthetic, Romanticism. 


\section{GİRIŞ}

Romantik sanat anlayışı, birçok noktadan başta Kant, Hegel, Schelling olmak üzere Alman idealistlerinin estetik hakkındaki görüşlerinden beslenerek biçimlenmiştir. Kant, Hegel ve Schelling gibi Alman idealistlerinin estetik kuramlarının temelinde ise deha estetiği yer alır. Sanatçıya ve sanat eserinin özgünlüğüne vurgu yapan Alman düşünürler, yüzyıllarca unutulan sanatçının varlığının sanat faaliyetinde başat rol oynadığını ileri sürerler. Önceleri sanatçının varlığını önemsemeyen sanat felsefesi, XVIII. yüzyılın sonlarına doğru romantik felsefenin etkisiyle dikkate değer bulunur. Kant'ın Yargl Yetisinin Eleştirisi'nde sanat eserini dehanın yaratımı olarak görmesi ve estetik yargının bu yaratım hakkında hoşlanma veya hoşlanmama şeklinde verilen bir beğeni yargısı olarak tanımlaması sanatçının varlığını estetiğin temel konusu haline getirir. Sanatçının gerçeği yansıtıp yansıtamadığı üzerinde duran kadim estetik ve sanatçıyı Tanrı'nın yarattıklarının kopyacısı olarak gören Orta Çağ estetiği Kant'ın savunduğu fikirler ile önemini yitirir. Hegel de sanatçının dehası sayesinde kendisinde mutlak olarak var olan akılsallığı biçimlendirerek sanat eserine dönüştürdüğünü söyleyerek sanatçıyı estetiğin temel çalışma nesnesi olarak ele alır. Schelling, Schiller ve Fichte gibi Alman idealizminin önde gelen isimleri, aralarında birtakım farklara rağmen sanatçının müstesna bir varlık olduğunu belirtirler.

Victor Hugo, Lamartine, Chateaubriand, Schiller gibi sanatçılar, Alman idealistlerinin sanat hakkındaki düşüncelerini benimsediklerini eserleriyle ortaya koyup kimi zaman eserlerine yazdıkları önsözlerde romantik sanatın ilkelerini belirlemişlerdir. Söz gelimi Cromwell'e Önsöz'de Victor Hugo, romantik sanatın tabiat ve ilhamdan kaynaklandığını şöyle ifade eder: "Şu noktayı ısrarla belirtelim ki, şiir ancak doğadan, gerçekten ve kendisi de bir gerçek ve bir doğa olan esinden (ilhamdan) öğüt almalıdır." (2005, s.56). Hugo'nun fikirleri Kant, Schelling gibi Alman idealistlerinin düşüncelerini hatırlatır. Schelling'e göre "gizemli, mucizevi yazının içinde saklı bulunan bir şiir olan doğayı" bir sanat eseri gibi görmek gerekir. (Soykan, 2006, s.14) Kant'ın (2006, s.193) şiiri hayal gücünün özgür bir oyunu olarak görmesi ile Hugo'nun şiirin ilhamdan kaynaklandığını iddia etmesi aynı bakış açısının bir ürünü olarak değerlendirilebilir.

Kant'ın ve Hegel'in sanatçının dehasına yaptıkları vurgunun yansımalarını romantik sanatçıların sanat anlayışlarında görmek mümkündür. Sanatçıyı özel bir varlık olarak değerlendiren Hegel, hayal gücünün üretici etkinliğini deha olarak değerlendirir. Sanatçının dehası sayesinde kendinde mutlak olarak akılsal olan şeyi alarak ona dişsal bir biçim verdiğini söyler. (1994, s.282) Başka bir ifadeyle malzemenin biçimlenmiş şekli olarak sanat, Hegel'in düşüncesi uyarınca deha denilen yaratıcı etkinliğin hayal gücünü harekete geçirmesiyle ortaya konulur. Hegel'in düşüncelerini aynen kabul eden romantik şair William Wordsworth, sanatın kaynağını tabiatta keşfeder; deha ve heyecanı sanatçının sahip olduğu temel vasıflar olarak değerlendirir:

Coşku Tabiattan gelir ve sakin haller

Aynı şekilde, hediyesidir Tabiatın:

Bu onun zaferidir; bu iki özellik

Onun gücünü teşkil eden kardeş boynuzlardır.

Bu yüzden deha, sökün ve heyecanin

Devridaiminden beslenmesi dolayısılala,

En iyi ve en saf arkadaşldir onun;

Doğruyu aramak için gerekli enerjiyi ondan alır,

Aklın o durağanlığını, aramadan bulduğu. (William Wordsworth, 2009, s.239)

Romantik sanat, Türk edebiyatına da ciddi anlamda tesir eder. Tanzimat Dönemi'nde Batı edebiyatına yönelen Türk edebiyatçılarının en fazla etkisinde kaldıkları akım romantizmdir. Türk edebiyatçılarının Batı düşüncesi ile yakın temasta bulundukları söz konusu dönemde romantik akımın, sanat ve edebiyatta Avrupa'da mutlak bir hâkimiyeti vardır. Öte yandan Divan şiiri geleneği terbiyesiyle yetişen ve insanın iç âlemine, hissiyatına önem veren Tanzimat nesli, romantizm ile daha kolay bir bağ kurar. Bu dönemde 
Namık Kemal'in Mukaddime-i Celâl ile Abdülhak Hamid'in Makber'in mukaddimesine koyduğu Birkaç Perişan Söz yazısı romantik bir duyuşla kaleme alınan metinler olarak göze çarpar. Namık Kemal, "Hugo dünyaya gelmese idi ben belki yazı yazmağa muktedir olamazdım" diyerek romantizmden ne derece etkilendiğini vurgular. (2013, s.423) Romantik akımın tesiriyle Türk edebiyatı hamiyet, vatan, milliyet, hürriyet gibi kavramlarla tanışır. Ayrıca tabiat, eskiden farklı bir şekilde şairin kendisini mutlu hissettiği ve benliğini duyurduğu bir evren olarak romantizmin etkisi ile adeta yeniden keşfedilir. $\mathrm{Bu}$ bağlamda Hamid'in Sahra kitabının romantik tabiat algısını Türk edebiyatına taşıdığını hatırlamakta fayda var.

Romantizmin Türk edebiyatına olan etkileri Tanzimat Dönemi’yle sınırlı değildir, romantik sanatın tesirinin Milli Edebiyat ve Cumhuriyet dönemlerine kadar ulaştı̆̆ını söylemek yanlış olmaz. Mehmet Emin Yurdakul, Ziya Gökalp gibi milliyetçi şairler romantik sanattan beslenirler. Özellikle Ziya Gökalp'in tarihe romantik bir bakışla yaklaşıp yeniden yorumlaması, ulus inşası sürecine büyük destek sağlar. Hasan Aksakal'ın belirttiği üzere Ziya Gökalp'in eserlerinde milli kültürün, evrensel medeniyetten daha öncelikli olduğu yönünde romantik milliyetçi temalar işlenir. (2015, s.16) Yahya Kemal ve Mehmet Akif gibi modern Türk şiirinin önde gelen şahsiyetleri Ziya Gökalp’ten anlayış olarak ayrılsalar da romantik bir bakışla tarih ve medeniyete yaklaşırlar. Cumhuriyet Dönemi'nde de birçok şair millî-romantik bir duyuş ile Anadolu'yu ya da Türk tarihi ele alır. Faruk Nafiz Çamlıbel, Arif Nihat Asya, Orhan Şaik Gökyay bu şairlerden sadece bazılarıdır.

Şair yönü kadar felsefeci yönüyle de tanınan Rıza Tevfik (1869-1949) hece vezni ile yazdığı şiirleriyle hece veznine geçmeye çalışan genç şairlere yol gösterici olur. Sanatı kadar, sanat ve felsefe üzerine yaptığı incelemeler ile öne çıkan Rıza Tevfik'in romantik bir sanat anlayışı ile şiirlerini kaleme aldığı söylenebilir. Tekke ve Halk edebiyatı hakkında incelemelerde bulunduğu gibi Halk edebiyatına özenerek şiirler kaleme alır. Mehmet Kaplan'ın dediği üzere Rıza Tevfik nefesleri ve koşmaları ile, herkesi, bu aletlerle güzel eserler vücuda getirebileceğine ikna eder. (1997, s.198) Ayrıca Halk edebiyatı üzerine yazdığı makaleleriyle Türkiye'de folklorun gelişmesinde önemli bir rol oynar. Fikirleriyle Milli Edebiyat temsilcilerine yön verdiği gibi hece vezniyle yazdığı şiirlerle aruz-hece tartışmalarında hecenin üstün gelmesine katkıda bulunur.

Rıza Tevfik, şair kimliği yanında felsefeci olarak da önemli hizmetlerde bulunur. "Ülkemizde ilk kez, felsefe ders kitabını yazmış ve bu derslerin programını yapmışıı. Hem lisede hem de üniversitede felsefe okutmuştur. Şiirlerinde felsefe yapmış ve yazılarında felsefeyi savunmuştur. Birçok makalesine 'feylesof' imzasını atmıştır." (Çubukçu, 1990, s.145) Özellikle Abdülhak Hamid'in etkisi ile şiirde felsefi konulara temas eden Serab-ı Ömrüm'ün şairi, Hamid'in şiirlerini felsefi açıdan tetkik ederek Türkiye'de edebî eleştiriye yeni bir saha açar. Abdullah Uçman'ın ifade ettiği gibi onun Abdülhak Hamid'in şiirine felsefi açıdan yaklaşması Türk şiirinde bu alanda yapılan ilk teşebbüstür. (1984, s.3)

Felsefeye olan merakı ve bu alanda yaptığı çalışmalar neticesinde Filozof Rıza olarak nam salan Rıza Tevfik, Dârülfünun'da verdiği estetik dersleriyle Türkiye'de estetik disiplinin tanınmasına katkıda bulunur. Derslerinde Kant, Baumgarten, Platon gibi düşünürlerin fikirlerini mütalaa eder; güzellik, tabiat, sanatçı ile âlim arasındaki farklılıklar, sanatın mahiyeti gibi konulara değinir. Daha önce estetik hakkında dile getirdiği fikirlerini Güzel Sanat Hakkında Manzum Bir Musahabe şiirinde tekrar eder. Sanatta realizm, romantizm, idealizm gibi ayırımlara gidilmesini hoş karşılamasa da Filozof Rıza'nın, söz konusu şiirinde anlattıkları birçok noktadan romantik sanat algısı ile benzerdir. Böyle bir durumun ortaya çıkmasında şairin romantizmin tesirinden kalması ve Türk edebiyatına romantizmi getirdiğini ileri sürdüğü Şair-i Azam Abdülhak Hamid'den beslenmesi belirleyici olduğu söylenebilir. ${ }^{1}$ Beş bölümden oluşan şiirde romantik sanat algısının tesiri barizdir. Söz konusu şiirin her bölümü ayrı ayrı ele alarak şiire yansıyan romantik sanat algısını incelemeye çalışacağız.

\section{Sanatçı}

\footnotetext{
${ }^{1}$ Abdullah Uçman, Rıza Tevfik'in şiire başlaması hakkında şöyle bir yorum yapar: "1895 yılından itibaren Mekteb, Maârif, Hazine-i Fünûn ve Resimli Gazete gibi devrin önde gelen dergilerinde yayımlanan ilk şiirlerinde, insanın, kâinata varlığını hissettiren "külli irade" karşısındaki aczini dile getirmeye çalışan Rıza Tevfik, gerek ele aldığı meseleler, gerekse ifade tarzı bakımından büyük ölçüde Abdülhak Hamid'in ve batılı romantik şairlerin izinde görülmektedir.” (2011, s.136)
} 
Romantik sanatın, daha önceki sanat anlayışlarından ayrılan yönlerinden birisi sanatçıya verdiği büyük kıymettir. Kadim estetikte, sanat faaliyeti mimesis çerçevesinde değerlendirildiğinden dolayı sanatçının iyi bir yansıtıcı olup olmadığ tartışma konusu yapılmaktaydı. Gerçeği, ideal olanı ya da olabilir olanı yansıtan sanatçının üzerinde duran kadim estetikçiler, sanat eserinin estetik değerini sanatçıdan bağımsız değerlendirirler. Benzer bir anlayışın Orta Çağ boyunca sürdürüldüğüne şahit olunur. Rönesans Dönemi'nde sanatçının kişiliğine yönelik bir ilgi doğar, klasisizm akımı ile birlikte bu ilgi daha da artar. Fakat sanat eserinin, sanatçının iç âleminin bir ifadesi olduğu ve sanatçının duygularının sanat eserinde yankılandığ düşüncesi ilk defa romantizmde savunulur. Berna Moran'ın ifade ettiği gibi romantizmde sanatçının özel bir duyarlılığa ve herkeste bulunmayan yaşantılara sahip olduğuna inanılır. (2008, s.102) Heyecan, coşku, ilhamdan kuvvet alma, deha sahibi olma romantik sanatçının bazı vasıfları olarak sayılabilir. Rıza Tevfik, Güzel Sanat Hakkında Manzum Bir Musahabe şiirinin birinci bölümünde sanatçıyı ele alırken romantik sanatçıyı hatırlatan özellikleri sıralar. Ona göre keder ve istıraptan beslenen sanatçı, insanlığın halet-i ruhiyesine heyecan lisanıyla tercüman olur. Sanatçıyı besleyen ve ona büyük bir ilham veren en büyük duygu ise aşktır:

Doğuşundan âşsk doğan ve aşk için yaşayan,

Gönlünde insâniyyetin ümîdini okşayan,

Onun sûr ü mâtemini, sevincini, gamını,

En güzel bir şekle sokup, halka kendi nefsini

-İnsanlı̆̆ın en samimi ve en müphem hissini-

Ifş̧a edip hoş gösteren, sanâyi-i edepten,

Ağlamanın ve gülmenin üslûbunu öğreten, (Bölükbaşı, 1949, s.18)

Aydınlanma Çağı'nda akla verilen büyük önem, insanın his yönünün ihmal edilmesine ve mekanik bir varlık olarak algılanmasına yol açar. Kant'ın eleştirel tutumu ile birlikte akıl ve his arasında bir tür denge oluşturulmaya çalışılarak insanın eşsiz oluşu dillendirilir. Romantik algı, insanın his yönünün kıymetine vurgu yaparak sanatçının iç âlemindeki zenginliğinin bütün insanlığın faydalanacağı değerleri ürettiğini varsayar. Rıza Tevfik, romantikler gibi sanatçının histen beslendiğini belirterek insanlığa kendi benliğinin karanlık yönlerini açtığını ifade eder. Ona göre sanatçı adeta kendinden geçercesine ilahi bir halenin örtüsü altında sanatını icra eder. Zaten romantiklerin, sanat ile din arasında bir tür bağlantı kurduğundan söz eden Melahat Özgü dünyayı, kâinatı hisle sarmanın dinin asıl mahiyeti olduğunu ve Schelling'in dinin bu niteliğinden hareketle sanat ile ilgili yeni bir yorum geliştirdiğini anlatır. (1949:s.735) Sanatçının hislerini yansıtabilmesi adına kendisini hislerinin coşkusuna bırakması ve yüce bir gayenin (insaniyetin) yararına adayabilmesi gerekir. Rıza Tevfik'in de şiirinde ileri sürdüğü üzere sanatçı, aşk gibi güçlü bir duygudan kuvvet alır fakat bu duygusunu insanlık adına kullanır. Bir yanıyla bireysel bir tutum sergileyen sanatçı öbür yanıyla kendisini insanlığa hizmet etme ülküsüne adar. Romantik sanatın önde gelen ismi Victor Hugo'nun şairin görevleri hakkında düşündükleri ile Rıza Tevfik'in sanatçıya yaklaşımı arasında benzerlik kurulabilir. Hugo'ya göre şair "yapıtlarında kişisel duygularını anlatmalıdır, çünkü onlar insanlığın bir parçasını içerir. Önemli olan şairin şarkılarında, insanın, doğanın ve olayların sesini birleştirebilmesidir. (...) Ayrıca şair uzakları görmeli, topluma rehberlik etmeli ve onlara gerçekleri anlatmalıdır." (Çılgın, 2007, s.60) Rıza Tevfik sanatçının, millî olması fakat aynı zamanda milleti aşan bir karakterin özelliklerini sergilemesi gerektiğini belirtir. Bilindiği üzere romantizm milliyetçiliğin yükselişe geçtiği bir dönemin sanat akımı olmasının yanında milliyetçilik fikrinden doğrundan ilham alır. Fakat romantik sanatçılar millî değerlere hapsolmayarak insanlık ülküsünü savunurlar. Bu bağlamda Victor Hugo'nun Les Burgraves piyesinde geçen "avoir pour patrie le monde et pour nation l'humanité" (Dünya vatanım ve insanlık milletim) fikrinin romantikler tarafindan kabul edildiğini söylemek gerekir. Birçok sanat ve estetik araştırmacısı da sanatçıların mensubu olduğu milletin değerlerinin ötesine geçebilmesi gerektiğini ileri sürmüştür. Söz gelimi Cemil Sena bu hususta şu düşünceyi paylaşır: "Sanatçıyı sadece ulusal bir sınır içinde bırakmak, sanatın çerçevesini fazla daraltmak olur ve onu biraz da fayda esasına bağlamak gibi, gerçek güzelliklerden uzaklaştırmak sayılır ve sanatçının kişisel değerlerini köreltir, özgürlüğüne engel olur.” (1972, s. 149) 
Bir sanatçının zamanını aşıp geleceğe intikal etmesini ve mensubu olduğu milletin sınırlarını aşmasını sağlayan hususların başında, genel manada insanlıkla ilgili konulara temas etmesi gelir.

Rıza Tevfik, sanatçının portresini çizerken onun ayırt edici niteliklerinden olan hassasiyetlerine vurgu yapar. Şair özelinde sanatçının ruh halinin değişiklik arz ettiğini bazen bülbül gibi şakırdadığını bazen bir aslan gibi kükrediğini, kederli olmasına karşın ümitsizliğe kapılmadığını, kendini dünyanın merkezinde gördügünü fakat bencil olmadığını belirtir:

Anlaşılmaz sebeplerle için için titreyen,

Ba'zan bülbül olan, ba'zan arslan gibi kökreyen

Hassâs olur, gamkîn olur, fakat bedbin olamaz.

Dünyâyı kendinde görür fakat hodbin olamaz. (Bölükbaşı, 1949:s.19)

Sanatçının iç âlemi ile ilgili romantizme gelene kadar ciddi bir değerlendirmede bulunulmamasına karşın kadim zamanlardan beri sanatçı aykırı bir varlık olarak görülmüş ve sanatçının eylemleriyle sıradan olanın dışında durarak yerleşik değerlere muhalefet eden bir kişiliğe sahip olduğu belirtilmiştir. Örneğin Sokrates, Atinalılara karşı kendisini savunurken şairlerin içgüdüyle, Tanrı'dan gelen bir esinle yazmalarına karşın ne dedikleri anlaşılmayan kişiler olduğunu bilmedikleri halde bildiklerini zannettiklerini söyler. (Platon, 1998, s.48) Sokrates'e göre şairler çılgınca davrandıkları için doğruya yaklaşmaktan uzaktırlar. Şairlerin marjinal bir kişiliğe sahip olması, Platon'un Devlet'te onlara karş1 olumsuz bir tutum takınmasına neden olmuştur. Romantik sanat, sanatçının marjinalliğine olumsuz yaklaşmak bir yana marjinalliğin sanatçının ayırt edici vasfi olduğunu öne sürer. Rıza Tevfik, söz konusu şiirinde sanatçının herkesin alışık olduğu davranışlardan saptığını ve bu sapmasının sanatına yön verdiğini söyleyerek romantizmin sanatçıya yaklaşımını benimsediğini ortaya koyar. Ona göre sanatçının yaşadığı keder onun en büyük kuvvetidir, sanatçı ilhamını doğrudan kederden beslenerek güçlendirir:

Keder âdî adamları ezip kıran bir yüktür.

Şâir için bâl ü perdir, onunla o yükselir.

Ilham ylldirımı ekser gam bulutuyla gelir.

Hayvan ancak acı duyar; keder etmez; edemez.

O, ma'nevî elemlerin hududuna gidemez.

Keder edebilmek bizim büyük hasletimizdir.

Bizim imtiyazımızdır, bizim kudretimizdir.

Odur piç ü tâb-ı ruûn lisâninı yaratan!

Felâketler lâzımıdır, bu lâhûtî kudretin (Bölükbaşı, 1949, s.19)

Rıza Tevfik, kederin her insanda aynı etkiyi bırakmadığını sıradan insanları yıktığını; sanatçının ise kederi sayesinde yükseldiğini belirtir. Üzüntü duymadan, 1stıraba gark olmadan bir sanatçının doğamayacağını ifade eden şair, hayvanın acı duyduğunu fakat kederlenmediğini belirterek insanın varoluş nitelikleri arasında kederin bulunduğunu belirtir. Kederlenmek için ise insanın büyük felaketler yaşaması gerektiğini anlatır. Şiirin ele aldığımız bölümünün açıklama kısmında Şair-i Azam Abdülhak Hamid Tarhan'ın sanatından örnek vererek şiirde ileri sürdüğü fikirleri temellendirmeye çalışır. Ona göre Hamid, "sevgili refikasını kaybetmeseydi Makber'i yazamazdı. Sanatkâr ancak çektiği elemler vasıtasıyla bütün insaniyyetin ruhunu tanıyabilir." (Bölükbaşı, 1949, s.18) Rıza Tevfik' in Hamid'i örnek olarak göstermesi iki açıdan önemlidir. Birincisi Hamid, romantik sanatın Türk edebiyatındaki ilk ve en önemli temsilcilerinden biridir. İkincisi Hamid, Makber'in mukaddimesine koyduğu Birkaç Perişan Söz ile Rıza Tevfik'i doğrulayan tezleri savunur. Hamid'in Makber'in vücuda gelmesinde yaşadığ kederin belirleyici olduğunu söylemesi, sıradan bir şiir yazmadığını belirtmesi ve ilhama yer vermesi, romantik sanat çerçevesinde ele alınabilir. Ayrıca kız kardeşine yazdığ 1 bir mektupta kederi ve kederli olmayı olumlayan ifadelere yer verir. Ona göre "1stırap mabud-1 ilahinin en doğru ve en büyük delilidir ki bizim şu âlemde sade hayal olmadığımızı bildirir. Ben uğradığım kederden anladım ki hiç değilse mevcudum. Bu da tesellidir." (Tarhan, 1995, s.361) Genel anlamda Hamid'in sanatına ve karakterine dikkat 
edildiğinde Rıza Tevfik'in Güzel Sanat Hakkında Manzum Bir Musahabe şiirinin portresini çizdiği sanatçının Hamid ile birçok açıdan benzerlik arz ettiği görülür.

Rıza Tevfik'in incelediğimiz şiirinin ilk bölümünde sanatçıyı ele alırken üzerinde durduğu bir mevzu da ilhamdır. Sanatsal yaratımda ilhama estetik kuramcılar tarafından önemli bir yer ayrılmıștır. Hegel, sanatçının dış dünyadan malzeme almasına karşın ortaya koyduğu eserin kendi ilhamının bir neticesi olduğunu vurgular. Ona göre sanatçı, kendisini işlediği konuyla tamamen özdeşleştirir ve düş gücü sayesinde konuyu iç âleminde biçimlendirerek cisimleştirir. (1994, s.290) Hegel, fantezi kurmayı sanatsal bir yetenek olarak görür ve sanatçının ilham sayesinde fantezi kurabildiğini ileri sürer. Hegel'in görüşlerinden hareketle ilhamı, bir konunun sanat eserine dönüşmesini sağlayan temel dinamik olarak ele almak mümkündür. Aynı zamanda "ilham, sanatçıların zanaat alanından çıkıp yaptıkları şeyden esinlenen özel bir üreticiler kategorisine girmelerinin aracını sağlar." (Townsend, 2002, s.170) Sokrates sanatçının esinlenmeden, kendinden geçmeden, yani aklı başındayken hiçbir şey yaratamayacağını söyleyerek sanatsal faaliyette ilhamın önemini belirtir. (Platon, 2011, s.33) Romantizmde ise ilham sanatsal yaratımda ilk basamak olarak görülür; sanatçının ilhamı sayesinde maharetini gösterdiğine inanılır. Romantik şair, William Wordsworth, ilhamı bir periye benzeterek sanatçının ilham perisi sayesinde kanatlandığını ifade eder:

İnsanoğlunun bütün yaratıcı güçlerini gölgede bırakan!

Ilham Perisinin yardımın isteyeceğiz bir kez,

O bizi ağırlayıp taşlyacak kanatlarıyla kalabalığın

Tehlikesi ve itiş kakışı üzerinden bir göstericinin

Sahnesine. (2009, s.53)

Sanatkâr ile âlim arasındaki farkı anlattığında tekrar ilham (esin) mevzusuna dönen Rıza Tevfik, sanatçının ilham yoluyla bilgi elde etmesinden ötürü âlimin ulaşamayacağı ve idrak edemeyeceği hakikatlere değindiğini anlatır. Bu şiirin dışında ilham ile ilgili iki yazı kaleme alır. İlham adlı yazısında ilhamın sanat eserlerinin anlaşılmasında önemli bir rolünün olduğunu söyler:

"Sanâyi-i nefiseye müteallik münakaşât ve tenkidâta en mühim ukde, şüphesiz ilham meselesidir. Herhangi şube-i nefîseye ait olursa olsun bir eserin, mahzâ sanat nokta-i nazarından klymetini tayin edebilmek için, evvel emirde o esere vücut veren avâmil-i muhtelife miyânında ilhâmın rolünü tayin etmek lâzım gelir ve ancak bu sayede ve bu nokta-i nazardan bir sanatkârı (artiste) bir hünerverden (virtuose) tefrik ve temyiz edebilmek mümkün olabilir.” (Bölükbaşı, 2018, s. 70)

Şaire göre hüner ile ilham birbirine yakın durmasına karşın aralarında ciddi bir ayırım söz konusudur. Onun açıklaması uyarınca ilham insanın benliğinin en müphem derinliklerinden ansızın zihne gelen hatırlamalar iken, hüner ise fizyolojik bir kabiliyetten ibarettir. Sanatta ilham, ruhtan kaynaklı bir durum olarak kabul edilmesine karşın hüner ruhu kalıba sokma melekesi olarak görülür. $(2018$, s.72) Riza Tevfik, Ilham Bir Artiste Ne Getirir? adlı yazısında ise ilhamı heyecan anında yaşanan bir coşkunluk olarak tanımlar. Fakat bu heyecanın korku anında yaşanan heyecandan farklı olduğunu, bediî bir özelliğe sahip olduğunu belirtir. (2018, s.204) İlham aynı zamanda Rıza Tevfik' in düşüncesine göre sanatçının yaratıcılığını ortaya koyan bir faktördür.

İlham, sanatçıyı tabiatın kaba taklitçisi olmaktan kurtaran bir unsur olarak değerlendirilir. Romantiklerin en fazla işledikleri konuların başında tabiat gelir fakat romantikler tabiatı ele alırken onu olduğu gibi yansıtma uğraşı içerisine girmezler; tabiatta duydukları sesleri, gördükleri manzaraları iç âlemlerinde işleyerek hislerinin rengine büründürürler. Bunu yaparken de ilhamın muazzam gücünden faydalanırlar. Romantik sanatçı nadiren kendinden önceki büyük sanatları örnek alır. Madame de Stael'in dediği üzere "şair klasik şiir yazıyorsa Yunan ve Roma şiirine öykünmek zorundadır, romantik şiir ise esinlenme ürünüdür.” (2005, s.40)

Rıza Tevfik'in sanatçının niteliklerini anlatırken üzerinde durduğu diğer bir mevzu özgünlüktür. Kural ve kaidelere bağlanmaktan uzak duran sanatçı ona göre ancak özgürce davranarak sanatını icra edebilir. Dabney Townsend de özgünlüğ̈ sanatın zorunlu bir koşulu olarak ele alarak ancak dehaların özgün olabileceğini söyler. (2002, s.134) Romantik sanatçılar alışıla gelen anlatım tekniklerinden vazgeçip yeni 
anlatım imkânları bulmaya çalışarak özgün bir üslup geliştirirler. Klasisizmin kalıplaşmış anlatım teknikleri ve belli başlı konularına karşı gelen romantikler, kendi üsluplarını oluşturmayı estetik bir ilke olarak görürler. Rıza Tevfik'in sanatçının kederini özgün bir biçimde dile getirdiğini söylemesi ile romantik sanata yaklaştığı gözlemlenir.

\section{Bir Sanatkâr Olarak Şairin Üstünlüğü}

Şairin diğer sanatçılar arasında müstesna bir yere sahip olduğu öteden beri savunulmuş ve şiir sanatının diğer sanatlardan üstünlüğü muhtelif sanatçılar tarafından farklı şekillerde ifade edilmiş̧ir. Şiiri güzel sanatların en üstünü olarak gören Kant'a göre "şiir sanatı imgelem yetisinin özgür bir oyununu, anlağın bir işi gibi yerine getirme sanatıdır." (2006, s.193) Alman düşünür, şairi de bir dâhi olarak tanımlayarak diğer sanatçılara göre imgeleminin gücünden daha fazla yararlandığını iddia eder.

Romantik sanatçılar ve romantik sanatın kuramcıları şiire ve şaire oldukça önem verirler. Nitekim şiir, romantizmde diğer sanat türlerine nazaran daha fazla yer işgal eder. Hatta romantiklere göre evrene şairane bakmak ve duyguları şairane anlatmak romantik sanatın temel nitelikleri arasında sayılır. Francis Claudon'un açılaması uyarınca romantizm her şeyden önce şiirsel yeniliği simgeler. Romantik şiiri, önceki şiirden ayıran en önemli özellik doğrudan doğruya insanın yüreğine seslenmesidir. (2006:s. 192193) Şairin sadece kişisel duygularını anlatmada değil, aynı zamanda insanlığın ortak duygularını anlatmada mahir olduğuna inanan romantikler, en güzel eserlerini şiir türünde vermişlerdir. Victor Hugo, Lamartine, Wordsworth, Chateabriand, Schiller başta olmak üzere romantizmin önde gelen isimlerinin çoğu aynı zamanda birer şairdirler.

Rıza Tevfik'in şair hakkındaki düşünceleri, romantik sanatçıların bilhassa Victor Hugo'nun şair ile ilgi düşünceleriyle aynı doğrultudadır. Güzel Sanat Hakkinda Manzum Bir Musahabe şirinin ikinci bölümünü şair konusuna ayıran Rıza Tevfik'e göre sanatçılar arasında heyecanı, kelimeler ile yani dil ile ifade edebilen tek sanatçı şairdir. Şair, evrendeki her şeyden bir anlam çıkarabilen ve bunu kelimelere dökebilen kişidir. Rıza Tevfik'in şairin gücünün, başvurduğu ifade aracından (dilden) kaynaklandığını söylemesi önemli bir tespittir. Sanatlar özü itibarıyla bir ifadedir ve her sanat türü kullandığı malzemenin imkânları dâhilinde bir ifade olanağına sahiptir. Şiir sanatının ifade imkânının dil olması, şairin dili kullanmadaki maharetinde kendisini gösterebileceği anlamına gelir. Rıza Tevfik şairin keder ve sstırabını şiire dönüştürürken takip ettiği yolu anlatır:

\section{Şâir, bir kendinin değil, bütün insâniyyetin}

Gizli ıztırâbâtını duyar, bilir; onlardan

Çiçek yapar, şafak yapar, gece yapar, gün yapar;

Hem tabiatta gördügü̈n suretten üstün yapar (Bölükbaşı, 1949, s. 19)

Rıza Tevfik, bir önceki bölümde sanatçının portresini çizerken de istırap ve kederin dile getirilmesi mevzusu üzerinde durmuştu. Şairin de genel olarak diğer sanatçılar gibi ıstırabını anlatırken herkesin pay alacağı hisleri dışa vurduğunu söyler. Burada şairin üstünlüğünün, hislerini tabiatın unsurlarını vasıta yaparak anlatmasından kaynaklandığını belirterek şairin diğer sanatçılar arasında müstesna bir mevkii işgal ettiğini ileri sürer. Rıza Tevfik, şair olmayı bir bilinç durumu olarak görür. Bu şekilde bir yaklaşım şairin karakterine açılık getirmesi açısından önemlidir. "Şair bir fikri, bir duygu-düşünce bütününü önce duyup sonra şiire dönüştüren adam olmaktan çok şairce yaşayan ve söyleyeceklerini şairce dile getiren kişidir." (Timuçin, 2005, s.36) Şairin duygularını tabiattaki unsurlar ile kurduğu özdeşleyim yoluyla anlatmasını sağlayan temel dinamik, şairane yaşamı seçmiş olmasıdır. Tabiatta kendi "ben"ini deneyimleyen şair portresini romantikler de gündeme getirirler. Rene Wellek, romantizmi anlatırken XIX. yüzyılın ayırt edici özelliğinin şiirin tabiatla kurduğu yeni ilişkiler olduğunu vurgular. Onun aktardığına göre romantik şair Lamartine, tüm kâinatı canlı ve ritmik olarak çalışan semboller ve işaretler sistemi olarak düşler ve şairin görevinin bir alfabe olarak görülen tabiatı sadece okumak olmadığını aynı zamanda onun ritmini duyarak yeniden üretmek olduğunu ileri sürmüş̧ür. $(2002$, s.302) Rıza Tevfik'in, söz konusu şiirinde, şairin kendisini tabiatta duyurmaya çalıştığını iddia etmesi, romantik sanat algisiyla uyumludur. 
Rıza Tevfik, şairin üstünlüğünü anlatırken üzerinde durduğu diğer bir konu da şairin insanın derunî âlemi ile irtibata geçebilme ve dış dünyada olup bitenlerin ardındaki manaya ulaşabilme istidadına sahip olmasıdır. Filozof Rıza'nın açıklaması uyarınca insan bir şair olduğunda varlığın sırrını görmeye muktedir olur; şairane bir bakış ile evrene bakıldığında eşyanın üstündeki gizem daha kolay anlaşılır. Şair, tabiattaki manayı keşfettiğinde onu kendi lisanıyla bir besteye dönüştürür. Bu ifade tarzı ilahi bir niteliğe sahiptir. Fakat şair asla sadece kendisi için şiir söylemez, duygularını başkalarının gönlünde duymak ister:

Şâir derin duygusunu bestelerde inlerse,

Sonra aks-ı sadâsını gönüllerden dinlerse

Bu sihre mûsikî derler.

\section{San'at zâten sihirdir.}

Müphemâta lisan vermek, can yaratmakla birdir. (Bölükbaş1, 1949, s.19)

Böylece Rıza Tevfik, bir sanatkâr olarak şairin üstünlügünü aynı zamanda görünenin ötesindeki sırları anlatabilmesine bağlar. Dış dünyadaki güzelliği eserine yansıtmak yerine güzelliği hisleriyle adeta inşa eden şair, ilahi bir vasfa sahiptir. Muhtelif yazılarında ve şiirlerinde şairin üstün meziyetlerinin olduğunu sürekli vurgulayan Rıza Tevfik'e göre şair, ürkütücü bir olayı bile mesela bir depremi insanda bediî heyecan uyandıracak tarzda anlatma istidadına maliktir. Bir âlim veya bir banker, depremi estetik zevk uyandıracak şekilde anlatmaktan mahrumdur. Çünkü insan, sanatkâr doğmadan ve kabiliyetini şairlikle ispat edemeden bediî bir biçimde anlatma kabiliyetine sahip olamaz. (2018, s.205) Şairliği müstesna bir imtiyaz olarak değerlendiren Filozof Rıza, Abdülhak Hamid'e hitaben kaleme aldığg şiirinde şairi şöyle izah eder:

\section{Sâir tabiatın sihr-i hüsnüne}

\section{Tutulmuş sayıklar bir dîvânedir.}

\section{Çılgın sevincine, derin hüznüne}

Sûret vermek ister; söz behânedir. (Bölükbaş1, 1949, s.102)

Rıza Tevfik'in özelliklerini sıraladığı şair profilinin birçok noktadan romantik şairlerin nitelikleriyle benzerlik gösterdiği oldukça barizdir. Şairin kederini anlatırken tabiatı malzeme olarak kullanması, ruhunu tabiatta duyması romantik sanatta dile getirilmiştir. Ayrıca Filozof Rıza, şairi, aykırı ve bireysel olmaya çalışan bir sanatçı olarak değerlendirirken de romantik düşünceye yakınlaşır. Şair, tabiatta gördüklerini taklit etmek yerine dönüsstürerek ve heyecanlarıyla onları yeniden tasvir ederek bireysel yönünü ortaya koyar. Tanpınar'ın dediği üzere romantizm, klasisizm terbiyesindeki akıl ve mantığın hâkimiyetinin yerine ferdiyetçiliği getirir. (2014, s.525) Rıza Tevfik de şairin üstünlügünü ifade ederken üzerinde durduğu asıl mevzu, şairin varlığını duyurabilmedeki özgürlüğü ve özgünlüğüdür. Öte yandan şairin ruhunun derinliklerine dalarak müphem alanları korkusuzca dile getirdiğini söylemesi, romantik sanatta savunulan bir düşüncedir. Sevim Kantarcıoğlu'nun aktardığına göre romantizmde "ruhunun karanlık hazinelerine korkusuzca dalabilen ve insanlığın bilincini genişleten, yeni değerler üreten şair, insanlığın kaderini değiştiren seçkin bir kişi, bir peygamberdir." (2009:s.100). Rıza Tevfik, romantizmde şair hakkında ileri sürülen görüşlerin benzerlerini incelediğimiz şiirinin dışında başka şiirlerinde de ifade eder. Örneğin bir dörtlükten oluşan San'at Hakkında şiirinde şairi şöyle tanımlar:

San'atta hüner (abes)ten istiğnadır.

İlhâm ile lâfza can veren, ma'nâdır.

Hak vergisidir o kabiliyyet bizde...

Şâirlik o imtiyâz-ı müstesnadır. (Bölükbaş1, 1949:s. 318)

Şair olmayı bir tür imtiyaz olarak gören Rıza Tevfik'e göre şairlik kabiliyeti Allah'ın verdiği bir lütuftur. İhamdan güç alan şairin temel niteliği ise hüner sahibi olmasıdır. Ele aldığımız şiirinden anlaşıldığı üzere Rıza Tevfik, romantik sanat düşüncesini bilinçli bir şekilde savunmaktadır. Nitekim benzer fikirleri 
romantik şair Schiller Şiirin Gücü adlı şiirinde işler. Şairin tabiattan ilham aldığını dile getiren Schiller, Rıza Tevfik' in de üzerinde durduğu şairin peygambervari niteliklere sahip olduğu fikrini dile getirir:

Sessizce hayat ipliğini bürmede onlar

Kardeş gibidir şair korkunç perilerle,

Ruhundaki eşsiz büyüyü kim çözer anlar,

Coşkun sazına karşı koyan var ise söyle!

Şair ki o peygamber asasıyla elinde,

Hükmetmede her duygun kalp üstüne her an,

Gezdirmede bir kalbi ölüm ülkelerinde,

Yükseltmede şaşkinca onu göklere buradan, (Schiller, 2001, s.24)

Schiller'in şairin coşkun ruhunu dışa yansıtırken ifade ettiği hususları birçok romantik sanatçı da anlatmıştır. Rıza Tevfik' in şaire bakışının romantiklerinkine benzemesinin tesadüf olduğu söylenemez. Bilakis söz konusu şiirinde savunduğu fikirleri bilinçli bir şekilde geliştirerek ve temellendirerek savunduğu görülmektedir.

\section{Sanat ile İlim Arasındaki Farklılık}

İnsanoğlunun medeniyet sahasında gelişmesini sağlayan iki unsur olarak sanat ve ilim, farklı amaçlara hizmet eden yönlere sahiptirler. Sanat ile ilmin nihai hedefleri insanın huzuru ve mutluluğudur. Fakat ikisinin kullandıkları yöntemler ve ortaya koydukları ürünler birbirinden farklı olduğu gibi insanda uyandırdıkları duygu ve düşünceler de farklıdır. Sanat pratik bir faydayı hedeflediğinde veya öğretme amacına sahip olduğunda bile estetik haz verme ilkesini bütünüyle bir tarafa it[e]mez çünkü sanatın varlık gayesi estetik haz ilkesidir. İlim; araştırma, doğrulama, tahlil etme, sonuçlara varma niyetinde iken sanat heyecan uyandırma, coşturma, yüzleştirme, hissettirme bazen de öğretme gayesini güder. Aralarında net ayırımlar olmasına karşın ilim ile sanat öteden beri birbiriyle kıyaslanmaktadır.

Rıza Tevfik de Güzel Sanat Hakkinda Manzum Bir Musahabe şiirinin üçüncü bölümünü sanat ile ilim arasındaki farklılığa ayırır. Ona göre bir sanat eserinde sanatçı dış dünyayı olduğu gibi taklit etmek yerine iç âleminde uyanan duyguları eşyayı vasıta ederek anlatır. Başka bir deyişle sanatçının işlediği unsurlardan ziyade duygularını dışa vurması önemlidir. $\mathrm{Bu}$ duyguları reel dünyada bütünüyle karşılayacak bir şeyin olmamasından ötürü sanatçı bir yaratıcı olarak kabul edilir. Bir önceki bölümde sanatın bir sihir olduğunu söylerken sanatçının "yaratıcı" kişiliğinden dem vuran şair, bu bölümde sanatçının üstünlüğünün yaratıcılığından kaynaklandığını ileri sürer. İlim ile sanat arasındaki farkı, sanatçı ile ilim adamının evrene yaklaşım tarzında ortaya koymaya çalışır. Öncelikle sanatçının evrene yaklaşım tarzına değinir:

Gamı gönülden koparıp çiçek yapmak hünerdir;

Bizim hünerimizdir!.. Gam işlenmemiş güherdir.

Onu biz işler bezeriz, şi're tahvîl ederiz.

Yaramızdan sızan kanla tablo teşkil ederiz.

Şübhesiz san'at sihirdir!...ona bir dem tutulan

-Aşk-ı âlemşümul için vicdanında yer bulan-

Her şeyi bambaşka görür:

\section{Cemadâtın fikrini}

Yıldızların gamzesini, dalgaların zikrini,

Akşamların hicrânını, gecelerin ye'sini,

Kibriyânın semâvâtı çalkayan sesini, 
Seherlerin ru'yâsını, serâbın hulyâsını,

Hattâ bir damlacık suyun, en gizli mâ'nasinı

Anlar, bilir. (Bölükbaş1, 1949, s. 21-22)

Rıza Tevfik, sanatçının eserinde ilim adamının yapmaktan mahrum olduğu birtakım edimlerde bulunduğunu açıklar. Ona göre insanın kederini bir çiçek üzerinde anlatmak ya da insanın bir yarasını tablolaştırmak hünerine sahip olan sanatçı, bütün âlemi farklı bir pencereden temaşa eder. Âlemde duyulmayan sesleri, görülmeyen manaları sanat yoluyla ortaya çıkarır. Böylece Rıza Tevfik, sanat ile ilim arasında bilgiyi elde etme yönteminden ziyade ontolojik açıdan bir ayırımın olduğunu vurgular. Onun açıklamasına göre sanatsal bilgi, ilmin bilgisinden daha üstündür. Çünkü sanat, ilim gibi evreni parçalara ayırarak ele almaz, evreni oluşturan unsurların insicam ve ahenginden varlığın manasına ulaşmaya çalışır. Rıza Tevfik'e göre ilim adamları sanatçıları geriden takip eden birer çocuk gibidirler:

İmin büyük farkı budur, o derin ma'rifetle!

İrân bahsinde âlimler-san'atkâra nispetle-

Çocukturlar...-tatmîn için tabiî merâkım-

Çocuk, oyuncaklarını kırar; cici böceğin

Yaldızlı kanatlarını koparır; bir çiçeğin

Parça parça edip yolar nâzenîn evrâkını!

Göremez onda hayâtın rengârenk âfâkını!..

Göremez onda güneşin mütekâsif nurunu,

Tâzeliğin işvesini, bahârın gururunu!...

Çocuk gözü anlayamaz güzelliğin resmini

Bilmek istediği şeyin harâb eder cismini. (Bölükbaşı, 1949, s. 22)

Rıza Tevfik, ilim adamının sanatçının yanında bir çocuk gibi kaldığını çünkü evrendeki unsurların bilgisine ulaşabilme amacıyla her şeyi parça parça ettiğini söyler. Mesela ilim adamının bir çiçeğin güzelliğinden haz almak yerine onu parçalayarak varlık bilgisine ulaşmaya çalıştığını anlatır. Sanatsal bakışı insanlığın ulaştığı olgunluk olarak değerlendirirken ilim adamının dışarıdaki güzelliği göremediğini, bilgiyi elde etmek için çevresini harap ettiğini belirtir. Rıza Tevfik, doğadaki güzellik ile sanatçının varlığı arasında zorunlu bir ilişki kurar. Onun düşüncesi dikkate alındığında doğadaki güzelliğin ortaya çıkarılması için sanatçının varlığı elzemdir. Bu bağlamda romantik sanat algısına yakın fikirler ortaya koyduğu söylenebilir. Çünkü romantikler de doğanın insandan bağımsız bir güzelliğinin olduğunu düşünmezler. Bilakis bazı düşünürler, "doğa güzelliğini kavramanın, ancak sanat güzelliği ile eğitsel bir yetişmeden sonra olanak kazanabileceğini öne sürerler." (Tunalı, 2007: 200) İlim adamı sanat güzelliği ile uğraşmadığı için doğa güzelliğini kavramaktan uzaktır.

İncelediğimiz şiirin söz konusu bölümünde Rıza Tevfik'in sanat ve ilim arasındaki farklılıklar hakkında ileri sürdüğü düşüncelerin romantik sanat ile kesişen başka yönleri de mevcuttur. Her şeyden önce Filozof Rıza'nın sanatta insanın iç âleminde meydana gelenlerin dış dünyadaki nesneler vasıtasıyla anlatıldığını, bu yüzden sanatçının doğayı taklit etmekten vazgeçtiğini ileri sürmesi romantikler tarafindan da dile getirilmiştir. Romantizmde de tıpkı Rıza Tevfik'in söylediği gibi sanat eseri bir yaratım ögesi olarak ele alınır. "Romantiklere göre çokluktan oluşmuş organik bir bütünlük olan sanat bir yaratmadır. Bu sebeple onlar, sonradan eğitim ve çalışma yoluyla elde edilen yeteneklerden ziyade sanatkârın doğuştan getirdiği yaratıcı dehaya önem verirler." (Çetişli, 2003, s.73) Şiirin bu bölümünde kısmen değinilen deha estetiği bir sonraki bölümde ayrıntılı olarak ele alınır. Şair bu bölümde sanatın farklılı̆̆ını anlatırken sanatçının şahsında keşfettiği olağanüstü vasıflarını ve sanatçının büyük idealleri yerine getirdiğini vurgulamak ile başlı başına romantik sanata göndermede bulunur. Şaire göre sanatsal yaratım hüner gerektiren bir faaliyettir ve hüner ancak deha sahibi insanların ortaya çıkarabileceği bir niteliktir. Bu açıklamalarıyla Rıza Tevfik, romantik sanatı görüşleriyle besleyen Alman filozof Kant'a 
yaklaşır. Kant'a göre sanat insani bir beceri olarak bilimden farklıdır. Bilimde deha yoktur, deha sanata kural verir ve bunu sanatı güzel sanata dönüştürünceye kadar yapar. (2011, s.172-177)

Romantik sanat üzerine önemli düşünceler ileri süren Hegel de sanatta içsel olanın dışlaştırıldığını belirterek sanatçının tinselliğinin öne çıktığını ifade eder. "Sanatçının işi, Hegel'in deyişiyle, insanın içselindeki başlangıçları görünürleştirmek, bu içselde etkinleşen geneli ve özseli ayrıksılaştırmak ve bunları bireyselleşmiş (veya tikelleşmiş) olarak görüleştirmek suretiyle, bu iki yönün farklılığını anlatmaktır.” (Kula, 2011, s.112). Rıza Tevfik, ilim adamının içsel olanı dışlaştırma kabiliyetinden yoksun olduğunu ve dış dünyayı bozduğunu söyleyerek romantik sanat anlayışına yaklaşır. Ona göre sanat, bilme göre günlük hayata daha yakındır ve daha geniş bir pencereden bakmayı seçtiğinden iyiyi, doğruyu, güzeli daha sağlıklı gösterir. Rıza Tevfik'in ilim ile sanat arasında ortaya koymaya çalıştığı ayırım sadece romantik sanatta değil, genel olarak estetik ve sanat felsefesinde belirtilmiş bir husustur. Aynı malzemeleri kullanmalarına karşın sanatın farklı yöntemler geliştirdiğini söyleyen Adnan Acar şu değerlendirmede bulunur:

"Bilim için insana, nesne ve gerekli bilgi birikimi yeterli iken, sanat için estetiğin yanında imge gücü, soyutlama ve tasarım yeteneği yani yaratıcı güç yani yeti gerekmektedir. İşte bu özellik, sanatı bilimden ayıran ve onu üstün yapan özelliktir. Oysa sanat ve bilim tarihi içindeki bazı dönemlerde, sanatsal düşüncede bunalımın olduğu, sanatsal düşüncenin bilimsel düşünce ve teknik çalışmalarla yarışamayacağı, görüşleri ortaya atılır. (2012, s. 18)

Sanatçıyı olağan dışı bir varlık olarak görmesinin yanında Rıza Tevfik'in incelediğimiz şiirinde ileri sürdüğü fikirleri-kolayca temellendirebilmesini, sanat felsefesi ve estetik disiplinine vakıf olmasına bağlamak mümkündür.

\section{Sanatçı ile Âlim Arasındaki Fark}

Güzel Sanat Hakkinda Manzum Bir Musahabe şiirinin dördüncü ve beşinci bölümleri sanatçı ile âlim arasındaki ayırıma odaklandığı için aynı başlık altında ele alınabilir. Bu bölümler, üçüncü bölümde ortaya konulan düşüncelerin daha da genişletildiği bir içeriğe sahiptir. Rıza Tevfik, sanatçının âlimden üstün olan meziyetlerini sıralayarak âlimin varlı̆g anlama ve anlatabilme noktasında sanatçıya yetişemeyeceğini ileri sürer. Ona göre sanatçı ile âlim arasındaki fark, evreni telakki edişlerinden kaynaklanır. Evreni parçalayarak ele alan âlim, eşyanın manasını anlamaktan uzaktır. Buna karşın sanatçı evrenin manasını anlatmakta mahirdir. Şair, önce sanatçının vasıflarını ortaya koyarak düşüncelerini doğrulamaya çalışır:

Bir hünerver cansız taşı hamur gibi yoğurur,

Ona güzel hayâlinden suret verir, can verir.

Dehâsı timsal-i hüsnü ra'şelerle doğurur

Elleriyle dokunduğu şeye hüsn ü ân verir.

Hâriçte güzellik yoktur; güzel onun zevkidir.

Hâriçte bir dalga vardır, nihâyetsiz bir deniz!

O dalgayı güfteleyen, besteleyen bizleriz.

Dâhi gökten nûr indirir bu kasvetli âleme

Bu mu'cize halk içinden çıkar yanlış belleme

Lâkin dehâ halkın değil hakkın bir ni'metidir:

Insanda Hâlık-ı hüsnün bedihi kudretidir.

İnsâniyyet ölür onsuz, Dâhî rûh-ı beşerdir.

O vahyile mübeşşerdir, sözü sûr-ı mahşerdir.

Ölü halk ihyâ eden, onun sisli ruhunda

Klyâmetler koparıp ta mu'cizeler gösteren, 


\section{O duygusuz ve bilgisiz şeye -lemh-i basarda-}

Yeni zevk u neş'e veren, yeni dilekler veren,

Mahzâ füsun-ı hünerle, eski ufk-ı nazarda

Bir fezây-ı hayâl açıp yeni âlem yaratan,

Bu cehennemden kurtarip, onu cennete atan,

Yırtıcı bir hayvân iken insanlığa sevk eden,

Şeytân iken melek yapan, âşinâyı zevk eden,

Hep o dâhî hünerverdir.. (Bölükbaşı, 1949, s. 21-22)

Rıza Tevfik, sanatçının niteliklerini açıklarken romantik sanatçıların da benimsediği deha estetiğine vurgu yapar. Deha estetiği, Kant ve Hegel gibi Alman idealistleri tarafından işlenmiş önemli bir konudur. Hem Kant hem Hegel sanatçının diğer insanlardan ayrılan özel bir yaradılışını olduğunu ifade etmişlerdir. Şiir sanatının kökenini bütünüyle dehaya dayandıran Kant'a göre bilim adamı ile sanatçı arasındaki fark dehadan kaynaklanır:

"Bilimde dehalar yoktur. Newton ile bir fizik öğrencisi arasındaki fark, niceliksel bir farktır ve ilke bakımından, öğrenmeye dönük sıkı çalışma ile kapatılabilir. Oysa dahi bir ressam ile yetenekli fakat dehanın dokunuşundan yoksun bir ressam arasındaki fark niteliksel bir farktır ve ne sebatlı çalışma ne de güçlü irade ile kapatılamaz. Kant şöyle söylüyor: Doğa Felsefesinin İlkeleri adlı ölümsüz eserinde Newton'un ortaya koymuş oldukları pekâlâ öğrenilebilir fakat şiir sanatına ilişkin talimatlar ne kadar eksiksiz olsa ve bu sanatın modelleri ne kadar mükemmel olsa da hakiki bir şiirsel dama içinde yazmayı öğrenemeyiz."(Altuğ, 2007, s. 195)

Rıza Tevfik'in de vurgulamak istediği asıl husus, âlimin bir dâhi olamayacağıdır. Ona göre âlim bir şey yarat[a]maz, Hegel'in ifadesiyle ruhunu dışlaştıramaz, eşyaya ruh vermez. Evrende güzelliğin olmadığını dile getiren Filoz Rıza, sanatçının dehasıyla güzeli yarattığını, hayal âleminde yeni değerler türettiğini iddia eder. $\mathrm{Bu}$ iddiası romantizmde de savunulmuştur. "Romantik anlayışa göre, değerler yaratılabilir, amaçlar belirlenebilir. Bu durum, kural ve yasalara uymaksızın, özgür imgelem gücüne dayanan sanatçının sanat yapıtını yaratmasına benzer. Sanatçı, sanat yapıtında kendi öznelliğini sergiler.” (Kula, 2010, s.49) Rıza Tevfik de sanatçının cansız malzemelere ruh verirken kendi öznel dünyasını ortaya koyduğunu söyler. Ona göre bir sanatçı sıradan insanlardan farklı bir şekilde eşya ve olaylara bakarak üslubunu oluşturur. Bu şekilde sanatçının bireyselliğini vurgulayan şair, romantik sanat algısını tekrar etmiş olur. "Romantik akımlarda birey, toplumdan daha önemli olmuş, insan değerin hem yaratıcısı hem de ölçüsü olmuştur." (Kantarcıoğlu, 2009, s.107) Okuyucu veya izleyici romantik bir eserde sanatçının bireysel yaşamını deneyimleyerek tümelin içerisinde görülemeyen tikeli keşfeder.

Sanatçının üstünlügünü dehaya bağlayan şaire göre deha sahibi olmak Allah vergisidir; bir insan istese de dâhi olamaz. Deha sahibi kişiler Allah tarafindan özel olarak seçilmiş ve vazifelendirilmiş kişilerdir. Her ne kadar sanat eserinde öznel davransa da sanatçı bütün insanlığa hizmet eder. Rıza Tevfik, iki açıdan sanatçının ilahi bir vasfinın olduğunu söyler. Birincisi, sanatçı halkı aydınlatarak adeta bir peygamber işlevi gördüğü için ilahidir. İkincisi, yaratıcı edimde bulunduğundan dolayı ilahi vasıfları haizdir. Sanatçının ilahi bir yönünün olduğu ve halkı yönlendirme gayesi taşıdığı Hegel tarafından vurgulamıştır. Alman düşünüre göre "sanatçının bir dönüştürme gücü vardır. Tinsellik ancak romantik sanatta en yüksek düzeyine ulaşır. Bu sanat mutlak içselliktir, özerkliğin ve özgürlüğünün bilincinde olan öznellik sanatıdır." (Albayrak, 2012:s. 295) Rıza Tevfik'in felsefeci yönü de göz önünde bulundurulduğunda Hegel'in romantik sanat hakkındaki düşüncelerine vakıf olduğu ve incelediğimiz şiire bu düşünceleri yansıtttı̆̆ söylenebilir.

Sözü âlime getiren şaire göre tabiattın bütün unsurları ilim için sadece bir malzemedir. Âlim ancak tahlil eder, tabiatın unsurları arasında kanunları keşfetmeye çalışır. Buna mukabil sanatçı tabiatının kendisine sunduğu malzemeyi şiire, müziğe ya da tabloya dönüştürür. Rıza Tevfik, şiirin sonunda sanat sayesinde insanlığın tekâmül ettiğini, gizli manaların açıklığa kavuştuğunu çünkü sanatçının gözünde âlemin başka göründüğünü belirtir. Ona göre bir damlacık gözyaşı bile sanatçı açısından büyük anlamları haizdir: 
Gözyaşı bir dam sudur, kimyâgerin indinde;

Onu bir de şâire sor!... Sonra gel gör kendine:

Eşk-i nedâmetse mutlak seni ka'rında boğar.

Bir deryadır!... -vicdan için- bir cehennem deryast...

Katre-i rahmetse, ondan kavs-i kuzahlar doğar;

Âlemi cennet gösterir sana rengin ziyâsı! (Bölükbaşı, 1949, s. 24-25)

Rıza Tevfik, sanatın üstünlüğünden bahsederken sözü sanatçının alımlayıcı öznelerde (dinleyici, okuyucu, izleyici) bıraktığı estetik etkiye getirir. Ona göre sanatçı, varlı̆̆ın anlamını eserinde ortaya koyar ve âlemi dönüştürerek anlatarak kişide muhtelif duyguların uyanmasını sağlar. Devrimler çağının akımı olan romantizm, sanatçının öznelliğine yaptığı vurguya rağmen, sanatın insanda belli duyguları uyandırması gerektiğini, insanların sanat sayesinde duygu ve düşüncelerinde birtakım değişimler yaşamalarının kaçınılmaz olduğunu savunmuştur. Rıza Tevfik'in sanatçının insanlar üzerinde bıraktığı etkiye değinirken de romantizme yaklaştı̆̆ gözden kaçmaz.

\section{Sonuç}

Romantik sanat ile birlikte varlı̆̆ yüzyıllarca görmezden gelinen ve genellikle kaba bir taklitçi olarak görülen sanatçı adeta yeniden doğar. Romantikler; tutkuları, arzuları, hisleri ve 1stırabıyla diğer insanlardan farklı olduğunu söyledikleri sanatçıyı bir dâhi olarak nitelendirirler. $\mathrm{Bu}$ dâhi insan romantiklere göre iç âlemini dış dünyadaki unsurlar vasıtasıyla dile getirerek sıradan birinin ulaşamayacağı bir mertebededir. Ayrıca duygu yoğunluğuna sahip olan sanatçı, görünenin ötesindeki manaları keşfedip insanlara duyurarak onları kendi iç âleminden pay almaya davet eder. Romantizme göre sanat, ruhun güzelliğini, deruni âlemin derinliğini ortaya koyarak bilimin yapamayacağı vazifeyi yerine getirir.

Rıza Tevfik'in Güzel Sanat Hakkında Manzum Bir Musahabe şiiri yukarıda ele alındığı üzere romantik sanat algısıyla kaleme alınmıştır. Şair, romantik bir bakış açısıyla her şeyden önce sanatçı öznenin marjinalliğine değinerek ve aynen romantiklerin yaptığı gibi sanatçının dehasını öne çıkararak diğer insanlardan ayrılan yönünü anlatır. Romantizmde şiir sanatına ve şaire verilen ehemmiyetin, Rıza Tevfik'in söz konusu şiirinde de vurgulandığı görülmektedir. Şiirin hiçbir yerinde romantizme değinmemesine karşın şairin baştan itibaren dile getirdiği fikirler romantizm ile uyumludur. Kant ve Hegel estetiklerinde ortaya konulan bazı düşüncelerin benzerlerini şiirinde tekrar eden şairin felsefe hakkında derin bilgiye sahip olması, sanat üzerine yorum yaparken sağlıklı çıkarımlarda bulunmasını sağlamıştır. İncelenen şiirde de görüldüğü gibi Rıza Tevfik, romantik sanat anlayışını birçok açıdan benimsemiştir. Gelecekte yapılacak başka çalışmalarda, Rıza Tevfik'in eserlerine romantizmin ne derecede tesir ettiği incelenerek sanatının oluşmasında belirleyici olan temel ögeler ortaya konulabilir.

\section{KAYNAKÇA}

Acar, A. (2012). Estetik. Ankara: Doruk Yayınları.

Aksakal, H. (2015). Türk politik kültüründe romantizm. İstanbul: İletişim Yayınları.

Albayrak, M. (2012). Estetik'in serüveni. Ankara: Akçağ Yayınları.

Altuğ, T. (2007). Kant estetiği. İstanbul: Payel Yayınları.

Bölükbaşı, R. T. (1949). Serab-ı ömrüm. İstanbul: Kenan Matbaası.

Bölükbaşı, R. T. (1984). Abdülhak Hâmid ve mülâhazat-l felsefiyesi. (haz. Abdullah Uçman). İstanbul: İstanbul Üniversitesi Yayınları.

Bölükbaşı, R. T. (2018). İlham. Sanat ve estetik yazıları içinde (haz. Abdullah Uçman). İstanbul: Dergâh Yayınları, s.70-76. 
Bölükbaşı, R. T. (2018). İlham bir artiste ne getirir? Sanat ve estetik yazıları içinde (haz. Abdullah Uçman). İstanbul: Dergâh Yayınları, s. 203-206.

Claudon, F. (2006). Romantizm sanat ansiklopedisi. (çev. Özdemir İnce-İlhan Usmanbaş). İstanbul: Remzi Kitabevi.

Çetişli, İ. (2003). Batı edebiyatında edebî akımlar. Ankara: Akçağ Yayınları.

Çılgın, B. (2007). Victor Hugo ve Namık Kemal'de romantizm; Cromwell ve Celâleddin Harzemşah'in karşılaş̧tırmalı incelenmesi. Yayımlanmamış yüksek lisans tezi, Ankara Üniversitesi Sosyal Bilimler Enstitüsü, Ankara.

Çubukçu, İ. A. (1990). Şair Rıza Tevfik Bölükbaşı ve felsefesi. AÜİFD, 31(40), 138-146.

Friedrich Schiller (2001). Felsefe ve şiir. (çev. Burhanettin Batman). İstanbul: Yaba Yayınları.

Georg Wilhelm Friedrich Hegel (1994). Estetik I. (çev. Taylan Altuğ, Hakkı Hünler). İstanbul: Payel Yayınevi.

Immanuel Kant (2006). Yargı yetisinin eleştirisi. (çev. Aziz Yardımlı). İstanbul: İdea Yayınevi

Kantarcıoğlu, S. (2009). Edebiyat akımları Platon'dan Derrida'ya. İstanbul Paradigma Yayıncılık.

Kaplan, M. (1997). Şiir tahlilleri I. İstanbul: Dergâh Yayınları.

Kula, O. B. (2010). Hegel estetiği ve edebiyat kuramı I. İstanbul: İstanbul Bilgi Üniversitesi Yayınları.

Kula, O. B. (2011). Hegel estetiği ve edebiyat kuramı II. İstanbul: İstanbul Bilgi Üniversitesi Yayınlar1.

Madame de Stael (2006). Klasik şiir ve romantik şiir. Romantizm antolojisi içinde (haz. Erdoğan Alkan). İstanbul: Varlık Yayınları, s. 39-40.

Moran, B. (2008). Edebiyat kuramları ve eleş̧tiri. İstanbul: İletişim Yayınları.

Namık Kemal (2013). Mektuplar Cilt II. (haz. Fevziye Abdullah Tanzel), Ankara: Türkiye Tarih Kurumu Yayınları.

Ongun, S. C. (1972). Estetik, sanat ve güzelliğin felsefesi. Ankara: Remzi Kitabevi.

Özgü, M. (1949). Alman romantizminde sanat anlayışı. DTCF Dergisi, (2)5, 735.

Platon (1998). Sokrates'in savunması. (çev. Niyazi Berkes). İstanbul: Cumhuriyet Dünya Klasikleri.

Platon (2011). Ion. (çev. Nihal Petek Boyacı). İstanbul: Kabalcı Yayınevi.

Soykan, Ö. N. (2006). Kuram-eylem birliği olarak sanat. İstanbul: MVT Yayıncılık.

William Wordsworth (2009). Prelüd. (çev. Nazmi Agı1). İstanbul: Yapı Kredi Yayınları.

Tanpınar, A. H. (2014). 19uncu asır türk edebiyatı tarihi. İstanbul: Çağlayan Kitabevi.

Tarhan, A. H (1995). Mektuplar I. (haz. İnci Enginün). İstanbul: Dergâh Yayınları.

Timuçin, A. (2005). Estetik bakış. İstanbul: Bulut Yayınları.

Townsend, D. (2002). Estetiğe giriş. (çev. Sabri Büyükdüvenci). İstanbul: İmge Kitabevi.

Tunal1, İ. (2007). Estetik. İstanbul Remzi Kitabevi.

Uçman, A. (2011). Rıza Tevfik'in sanat ve düşünce dünyası. İstanbul: Dergâh Yayınları.

Victor Hugo (2005). Cromwell'e önsöz. Romantizm antoloji içinde. haz. Erdoğan Alkan. İstanbul: Varlık Yayınları, s. 50-56.

Wellek, R. (2002). Edebiyat tarihinde romantizm kavramı. (çev. Sıddık Yüksel). Dinbilimleri Akademik Araştırma Dergisi, (2), 273-320. 